Historic, Archive Document

Do not assume content reflects current scientific knowledge, policies, or practices. 

62.34

\section{RIVERBANK GARDENS}
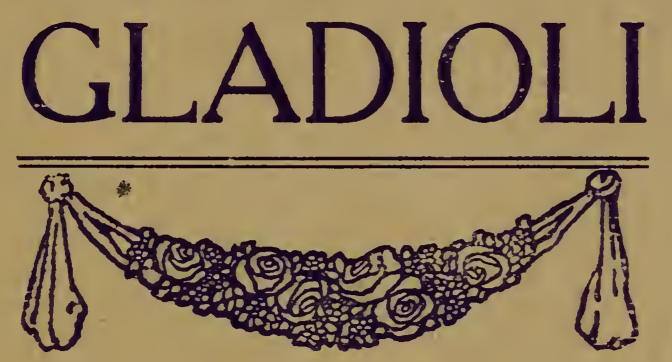

$*$

PRICE LIST 1916-1917 



\section{RIVERBANK GARDENS}
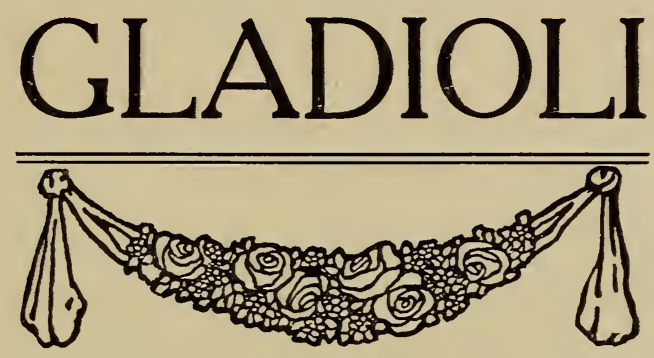

PRICE LIST 1916-1917

RAYMOND W. SWETT

SAXONVILLE : MASSACHUSETTS

Visitors are always welcome at my fields, especially during August and September when stock is in bloom. Saxonville is easily reached by trolley from Framingham. The trip from Boston or Worcester by the Trolley Air Line is especially enjoyable, transferring at Framingham Junction. 


\section{IMPORTANT}

While I exercise the utmost care to have all stock true to name, I give no warranty, express or implied, as to crop and will not be responsible for results other than to replace stock not true to name. ORDERS from unknown parties must be accompanied by cash or satisfactory reference. Terms are net 30 days, $5 \%$ for cash with order, $2 \%$ in 10 days from date of invoice.

REMITTANCE may be made by registered letter, check, post-office or express money orders, or fractional parts of a dollar in postage stamps. Make post-office orders payable at Framingham.

PRICES as listed supercede all previous lists and include postage paid to destination, 6 at dozen rate, 25 at one hundred rate. If you wish package insured, add five cents to cover cost.

SizE. Some persons seem to think that to get good blooms the bulbs must be enormous size. Such is not the case as some varieties never grow larger than $1 \frac{1}{4}$ inches. All bulbs I send out will be fully matured and large enough to bloom satisfactorily.

Culture. Gladioli do best if planted in a light soil in the full sun but do well on any soil if not too shaded. Fertilize well with a good grade of commercial fertilizer planting fully six inches deep, by four inches apart. Don't let them get too dry. Cultivate freely and dig in October cutting off the tops close to the bulb. After thoroughly dried store in a cool, dry, dark, frostproof cellar. 


\section{RIVERBANK GARDENS}

\section{MONTBRETIA}

These summer flowering bulbs are proving more and more popular both for massing amongst shrubbery and perennials and for cut flowers. They add a touch of dainty elegance to a vase of Gladioli or Dahlias. Growth is similar to the Gladioli with branching spikes of star shaped flowers. Plant early in May digging and storing same as Gladioli. 25c per dozen; per 100, \$1.50; \$10 per 1000.

\section{BOQUET PARFAIT-Vermillion.}

Crocosmeaflora-Orange red, brown tips.

FIRE KING-Orange center, brown tips.

Fleuve Jaune-Yellow.

GERBE D'OR-Golden yellow.

Germanica-Brilliant scarlet. Extra.

GRANDIFLORA-Orange yellow.

KING EDMUND-Pure yellow, brown blotch.

Nigricans-Dark foliage. Yellow flowers.

Prins VAN ORANGe-Large orange flowers.

PyRAmidalis - Red with lighter tips.

RAYON D'OR-Dark yellow. Very bright.

SOLEIL CoUChant - Yellow center, orange tips.

Riverbank Mixture-Yellows, reds, browns, etc., 15c per dozen; per 100, \$1. 


\section{RIVERBANK GARDENS}

\section{PRIMULINUS HYBRIDS}

There is little wonder at the increasing popularity of this type. Far more artistic and decorative than the larger types. Wherever shown the "hooded beauties" win most attention.

AnNy. Beautiful bronzy shade. Each, 50c.

Asia. (Award of Merit 1915). The best of all the Prims. A clear rosy pink suffused silvery rose inside, and a pale throat. Beautiful shape. Each, $\$ 2$.

Aurora. (Award of Merit, 1915). A most beautiful bright orange yellow flower of great substance. Each, \$1.

CONQUeror. Large pure creamy yellow. Each, 50c.

FE.Uille Mort. Ashy rose. "Dying embers." Each, 50c.

Gold Drop. (Kunderd). Very large pale primrose heavily ruffled. Crimson lines in lower petals. Tall heavy spike. Each, \$2.

IDA. Orange yellow. Each, 50c.

JANE. Salmon yellow. Each, 50c.

Mrs. Grullemans. Very large pure golden yellow. Award of Merit, 1916. Each, \$1.

Red QueEn. Large vivid scarlet. Each, 75c.

Royal Sovereign. (Award of Merit, 1915). Large dark yellow. Each, 50c.

Violet QueEN. Dark purple maroon. Each, 50c.

SEEDLINGS: ranging in color from pale cream to fiery crimson. Very early flowering and strong growers. Extra. Each, 5c; 50c per dozen; per 100, $\$ 4$.

KUNDERD's HYBRIDS : containing many ruffled types and "Glory" characteristics. Each, 10c; $\$ 1$ per dozen; per 100, \$7.50.

SPECIE: the true type as originally found in Africa. pale golden yellow. Invaluable for hybridizing. Each, 10c; per dozen, \$1. 


\section{HIGH QUALITY MIXTURES}

Blue Mixture. The finest blue mixture grown, containing the cream of the mixtures put out by most all the other growers. Each $5 c ; 50 c$ per dozen.

White AND Light. This contains the best selected lighter shades from Groff's Hybride. Each 5c; 50c per dozen.

YELLOW MixtuRE. Every one of these is a pleasing surprise. Fine combination all yellow. Each $5 \mathrm{c} ; 50 \mathrm{c}$ per dozen.

Popular Mixture. This is a well balanced mixture of all named sorts selected to fill the range of colors from white to darkest crimson. Per dozen, 35c; \$2 per 100.

Riverbank HyBrids. These are all seedlings of my own growing and are selected with care, all of the poor varieties being discarded. It was from these seedlings that I took the four varieties winning me four Certificates of Merit this year. Each 5c; 50c per dozen.

Primulinus Hybrids. By crossing the African Primulinus with the large flowering garden types we got these butterfly hybrids ranging in color from creamy white to deep crimson and violet. Very dainty and decorative. Each $5 c ; 50$ c per dozen; per 100 , $\$ 4$.

Surprise Collection No. 1. For one dollar I will pack up a box of twelve bulbs every one different and every one a good named variety. Value $\$ 1.50$.

Surprise Collection No. 2. For two dollars I will make up a collection all different and worth at least $\$ 2.50$. 


\section{LIST OF VARIETIES}

AmErica. (Groff). Beautiful soft shell-pink, very large. Each, $5 c ; 25$ c per dozen; per 100, $\$ 1$.

AnNy Wicman. (Hopman). Pale clear yellow with small red flush in throat, good sized flower. Very early. Each, 5c;25c per dozen; per 100, $\$ 1.75$.

Attraction. (Childs.) Bright glowing cerise with white centre and throat. Very good. Each, 10c; \$1 per dozen.

Augusta. (Hallock). Strong stiff spike, medium size flowers, pure white with purple stamens. Fine for forcing. Each, 5c; 25 c per dozen; per 100,\$1.

A. W. Clifford. (Kunderd). Old carmine red with lighter throat. Erect and vigorous. Early. Each, 50c; \$5 per dozen.

Baron J. Hulot. (Lemoine). Medium size, dark purple flowers on a long strong spike. Each, 5c; 25c per dozen; per $100, \$ 1.25$.

BlERIOT. (Bos). Tall rank grower with 8-10 florets wide open at a time of a clear salmon red with white throat and red blotch. Extra. Each, 20c; \$2 per dozen.

Blood Spot. (Kunderd). Smoky old rose shading lighter in throat with blood red spot in throat. Each, 20c; $\$ 2$ per dozen.

Blue JaY. (Groff). Not to be confused with Hulot. Beautiful pale blue with white blotch. Large open flower. Spike strong and well filled. The best blue to date. Each, 20c; \$2 per dozen.

BREnCHLEYensis. (Youell). One of the oldest and most popular of the hybrids. Vivid scarlet flowers of medium size but so many open at one time they make a very brilliant display. Each, $5 c ; 25$ c per dozen; per $100, \$ 1$. 


\section{RIVERBANK GARDENS}

California. Dark lilac with cream throat lined lilac. Fine spike. Each, 10c; \$1 per dozen.

Catherina. (Velthuys). Pale lavender with large maroon blotch tipped white. Each, 75c; $\$ 7.50$ per dozen.

Cattleya. Beautiful lilac rose. Each, $10 c ; \$ 1$ per dozen.

Chief Oshkosh. (Mehlmann). Light salmon rose with a red spot on white ground. Each, 15c; $\$ 1.50$ per dozen.

Chicago White. (Kunderd). The earliest white. Extra good forcer. Each, 10c; 75c per dozen.

Christine M. Kelway. (Kelway). Pale shell pink with pale yellow throat. Light crimson blotch in throat. Each, 25c; $\$ 2.50$ per dozen.

Clear Eye. (Kelway). Large, open, brilliant scarlet flower with clear white eye. Very tall, strong healthy spike. Each, $15 \mathrm{c} ; \$ 1.50$ per dozen.

Cissy. A tall strong grower. Creamy white ground spotied and blotched rose, crimson lines in throat. Each, 5c; 50c per dozen.

Clarese. Large open floret of beautiful cerise with a carmine line. Each, 20c; \$2 per dozen.

Columbia. (Childs). Light orange scarlet, freely blotched and penciled with bluish purple. Each, 5c; 25c per dozen; per 100 , $\$ 1.50$.

CRACKERJACK. Rich velvety dark red. Throat spotted with yellow and maroon. Very good. Each, 5c; 25c per dozen; per $100, \$ 1.50$.

Czar Peter. (Velthuys). Clear dark wine red, white stripe. Large well shaped flower. Each, 5c; 50c per dozen.

Desdemona. (Vilmoren). Dark rose with yellow throat. Maroon feathering. Each, 10c; $\$ 1$ per dozen. 


\section{RIVERBANK GARDENS}

Distinction. Fine clear dark mahogany, tall and strong. Each, $35 \mathrm{c} ; \$ 3.50$ per dozen.

ELDORADO. (Bos). Bright primrose with a fiery scarlet feathering in throat. Fine. Each, 20c; $\$ 2$ per dozen.

Electra. Very large, light scarlet shaded rosy red with white stripe on lower petals. Extra fine every way. Each, 10c; 75c per dozen.

Elisabeth B. Sampson. (Swett). The best blue in existence. A tall vigorous straight spike set with twenty-five to thirty buds. Eight to ten wide open clear blue flowers open at once. The darker blue blotch brightens up the floret wonderfully. Each, \$1.

Elizabeth Kurtz. (Pfitzer). Very good pure white. Each, $10 \mathrm{c} ; \$ 1$ per dozen.

EMPRESS OF InDIA. (Velthuys). Rich dark velvety red with white stripe. Very beautiful color. Strong grower and very good. Each, 5c; 25c per dozen.

Enchantress. Very fine pale lilac pink. Highly recommended. A very excellent color. Extra. Each, 10c; \$1 per dozen.

Europa. (Pfitzer). Pure snow white. The best white in existence. Each, 10c; 75c per dozen.

Evaline. Violet underlaid terra-cotta. Very striking. Each, 5c; 50c per dozen.

FRED WIGMAN. Large open salmon red flower with a white blotch. Very beautiful. Each, 5c; 35c per dozen; per 100, $\$ 2$.

George Paul. (Lemoine). Deep wine red. Large open flower. Each, 5c; 25c per dozen.

GLORY. (Kunderd). Light cream pink with crimson blotch. Ruffled edges. Very heavy spike. Each, 5c; 50c per dozen; per $100, \$ 3$. 
Glory of Holland. (Velthuys). A new pure white with lavender anthers. Large flowers well set on strong spike. Extra. Each, 5c; 35c per dozen; per 100, $\$ 2$.

Glory of NoORdwiJk. (Alkemade). Very large flowers of soft primrose yellow with deeper yellow in throat. Tall spike often 10 or 12 flowers open at one time. Best yellow yet introduced. Each, $\$ 1 ; \$ 10$ per dozen.

Golden Kinc. (Black). Bright yellow open flowers with large crimson blotch. Tall and strong. Each, 10c; 75c per dozen; per $100, \$ 5$.

Golden West. Brilliant orange with darker orange mottled throat. Very beautiful. Each, 10c; 50c per dozen. (See PACHA).

Gigantic. Large pure glistening white with pale stripe of lilac in lower petals. Each, 20c; \$2 per dozen.

Goliath. Extremely large, wide open dark wine violet. One of the best. Each, 75c; \$6 per dozen; per 100, $\$ 50$.

Grande Blanche. Creamy pink flushed white. Each, 10c; $\$ 1$ per dozen.

Crand Violet. Maroon edge, shading to violet in the throat. A good dark color. Each, 5c; 50c per dozen.

Halley. (Hogewoning). Very large salmon pink flower. Tall grower and very early. Each, 5c; 25c per dozen; per 100 , $\$ 1.25$.

HOHENZOLleREN. Light salmon pink with reddish blotch. Large flower. Very good. Each, 5c; 35c per dozen.

Hubertus. (Velthuys). Pale clear lavender, flaked darker on edges. Each, 15c; $\$ 1,50$ per dozen. 


\section{RIVERBANK GARDENS}

Hyde PARK. (Baer). A new introduction. Extra good for cut flowers. Large open florets well set on long spike, nearly white, flaked pale pink, primrose throat. Each, 10c; $\$ 1$ per dozen; per $100, \$ 7$.

IDA VAN. (Kunderd). Brilliant Lincoln red with slightly darker shade on lower petals. Large wide open flowers on long spike. Each, 10c; \$1 per dozen.

INDEPENDENCE. (Woodruff). Very large rosy scarlet flowers. Spike is long and stiff. Extra good for cutting. Each, 5c;25c per dozen; per 100, $\$ 1$.

INTENSITY. Bright flame scarlet white throat dotted and spotted scarlet. Effective. Each, 15c; \$1.50 per dozen.

KING OF THE YELLOws, Light canary yellow with tints of pink in throat. Strong grower. Each, 5c;35c per dozen.

KLONDYKe. (Banning). Lemon yellow with crimson blotch. Each, 5c; 25c per dozen; per 100, \$1.75.

KoRANAE. Fiery orange red with white lines. Each, 20c; \$2 per dozen.

LADY HowARD DE WALDEN. Sulphur yellow with prominent red blotch. Each, 5c; 50c per dozen.

LA PERLE DU JaRdin. Pale pure yellow without any markings. Each, 10c; \$1 per dozen.

LA Prophetesse. (Lemoine). Good sized flower of creamy white and red blotch on lower petals. Each, 20c; \$2 per dozen.

LA Tendresse. (Bos), Large. Clear salmon rose with carmine stripe on lower petal. Blotch of darker salmon in throat. Extra. Each, 25c; $\$ 2.50$ per dozen.

L'IDYLlE. (Bos). Pale yellow very beautifully set off with a dull scarlet blotch. One of the brightest and very early. Extra. Each, 20c; \$2 per dozen. 
Liebesfeuer. (Fitscher). A magnificent large flowering dark scarlet. A prize winner. Extra fine. Each, 20c; $\$ 2$ per dozen.

Lily LeHMANN. (Alkemade). Extra fine lily shaped white, very slightly shaded delicate pink. Fine. Each, $10 \mathrm{c} ; 35 \mathrm{c}$ per dozen; per $100, \$ 2.50$.

L'IMmACUleE. A splendid pure glistening white loosely arranged. Very effective for cutting. Each, 10c; \$1 per dozen.

LOVELINESS. (Van Konijnenburg). Very large open cream colored floret, suffused apricot in throat. Flowers well placed on spike and 12-15 open at once. Strong grower and extra fine. Each, 10c; $\$ 1$ per dozen.

MAHONY. Good strong spike of clear dark mahogany. Each, $50 \mathrm{c} ; \$ 5$ per dozen.

Master Wieburtus. (Velthuys). Rosy lilac with white blotch. Each, 25c; $\$ 2.50$ per dozen.

MASTER WIETSE. (Velthuys). Large compact spike of dark violet shaded purple. Each, 5c; 50c per dozen.

MaY. (Crawford). While the flower is medium sized it is excellent for cutting. Pale flesh pink flaked darker. Each, 5c; 50 c per dozen.

Meadowvale. (Cowee). White with flake of crimson in the throat. Ten to twelve open at one time. Plant vigorous, spike straight and strong. Each, $5 \mathrm{c} ; 25 \mathrm{c}$ per dozen; per 100, \$1.50.

Meteor. (Pfitzer). Bright nasturtium red, blotch of carmine on lower petals. Flowers large and well opened. Spike straight, tall and strong. Extra fine. Each, 25c; $\$ 2.50$ per dozen.

Mont Cenis. White, faintly streaked pink. Each, 10c; $\$ 1$ per dozen. 


\section{RIVERBANK GARDENS}

Mr. MARK. Fine bright lavender blue with white blotch and faint purple lines in throat. Each, 50c; $\$ 5$ per dozen.

Mrs. Francis King. (Coblentz). Flame pink, very large flowers well expanded on very long spike. Excellent for cutting. Each, 5c; 25c per dozen; per 100, \$1.25.

Mrs. Frank Pendleton, Jr. (Kunderd). Bright light pink with crimson blotch. Wide open, large flower. Long, well filled spike and tall strong grower. Each, $15 \mathrm{c} ; \$ 1.50$ per dozen.

Mrs. O. W. Halladay. (Kunderd). "Peaches and cream." Clear flesh pink with pale cream throat. Extra. Each, 75c; $\$ 7.50$ per dozen.

Mrs. Velthuys, (Velthuys). Fine bright fiery blood red. Silver medal, London, 1914. Each, $\$ 2.50$.

Mrs. WatT. Extra nice clear wine red. Each, 15c; $\$ 1.50$ per dozen.

Nezenscott. (Childs). Bright scarlet, with dark crimson blotch and white penciling in throat. Very showy. Tall and vigorous. Each, 10c; 50c per dozen.

NiaGARA. (Banning). Soft nankin yellow. Flowers large and very graceful form. One of the best. Each, 10c; 50c per dozen.

Norma Dee Childs. (Childs). Large open flower of delicate shell pink mottled darker. Cream throat. Extra. Each, 15c; $\$ 1$ per dozen.

PACHA. This variety is the one usually sent out as GOLDEN WEST which it so closely resembles as to require minute inspection to distinguish the difference. Fine golden orange flaked and spotted darker. Each, 10c; 50c per dozen.

Panama. (Banning). Resembles America but a shade deeper pink and larger flower. Better in every way. Each, 10c; 50c per dozen. 
PEACE. (Groff). Very large open white with pale carmine blotch on the lower petals. Late but very good. Each, 10c; 75c per dozen.

Pink Beauty. (Van Thol), Rose pink with darker blotch. The earliest. Each, 5c; 25c per dozen; per 100, \$1.

Pink Perfection. (Hopman). Very large beautifully formed flower of a delicate appleblossom pink. Very fine. Each, 10c; $75 \mathrm{c}$ per dozen.

President Wilson. Bright rose with cream throat. Rose blotch in throat. Very long spike. Each, 10c; \$1 per dozen.

Pride of Hillegom. (Velthuys). Very large floret of bright scarlet. Long heavy spike. The best of its color. Each $\$ 2.50$.

PRINCE OF WALES. Clear salmon without a spot of color. Very large open flower on long spike. Each, 25c; \$2.50 per dozen.

Princepine. (Kirchhoff). Clear bright scarlet crimson with white blotch. Similar to Princeps but more flowers open at once. Extra fine. Each, 10c; \$1 per dozen.

Princeps. (Van Fleet). Dazzling dark scarlet with white blotch. Very large open flower. Good. Each, 5c; 25c per dozen; per 100, \$1.25.

Princess Alteri. Pure white large flower with wine blotch and throat. Each, 10c; \$1 per dozen.

Princess Juliana. (Bos). Bright rosy salmon with white - throat lined with deeper pink. Very large open floret. Extra. Each, 25c; $\$ 2.50$ per dozen.

QueEN Wilhelmina. Very beautiful large open flower of a delicate appleblossom pink with darker clotch on lower petals. Extra good. Each, 10c; \$1 per dozen.

RED EMPEROR. (Groff). An extremely large well expanded flower on long, heavy spike. The best clear blood red. Each, 50 c; $\$ 5$ per dozen. 


\section{RIVERBANK GARDENS}

Red Queen. Very fine bright scarlet. Good. Each, 5c; 50c per dozen.

$\checkmark$ Rev. Ewbank. (Velthuys). Extra. Pale lavender with pale creamy blotch. Slight maroon mark deep in throat. Each, 25c; $\$ 2.50$ per dozen.

RosA LindT. Butterfly shaped bloom of bright carmine with darker throat. Good. Each, 20c; \$2 per dozen.

Rosea Superba. One of the best of the rose pinks. The florets are well spaced to show to best advantage. Clear rosy lilac with pointed carmine blotch. Each, 10c; \$1 per dozen.

Rosella. (Cowee). A very open spreading flower of a charming deep lavender. Fine for bedding. Each, 10c; $\$ 1$ per dozen.

Rochester WHite. (Thomann). Absolutely pure white even to the stamens. A fine variety, large open flower. Each, 20c; $\$ 2$ per dozen.

Rouge ToRch. Very fine white with carmine torch in the throat. Good. Each, 20c; \$2 per dozen.

SCARSDAlE. (Cowee). Immense lavender pink, shaded dark rose. Each, 5c; 35c per dozen; per 100, $\$ 2.50$.

SchWABEN. (Pfitzer). A clear sulphur yellow with very small brown spot in throat. Very robust grower with tall, strong spike. Each, 15c; $\$ 1.50$ per dozen.

ShARMON Swett. (Swett). Very large dark fiery scarlet flowers with white blotch heavily penciled dark blood red. Heavy vigorous spikes fully $51 / 2$ feet tall carrying 10-12 open florets with 20-25 buds to come. Dark, healthy, wide foliage. Eäch, \$1; $\$ 10$ per dozen.

SiEger. (Pfitzer). A large glorified Brenchleyensis. Extra fine. Spike long and well filled. Each, 20c; $\$ 1$ per dozen.

SUlPHUR KING. (Childs). The very best yellow. Each, 25c; $\$ 2.50$ per dozen. 


\section{RIVERBANK GARDENS}

SHAKESPEARE. (Souchet). White slightly suffused with rose. Good sized flowers well opened. Tall strong spike. Each, 10c; $\$ 1$ per dozen.

THE KING. (Cowee). Rich deep old rose with cream blotch on lower petals; fine open flower. Each 5c; 50c per dozen.

Victory. (Groff). Clear primrose yellow. Good form and long sturdy spike. Large open flower. Each, 5c; 35c per dozen; per 100, $\$ 2.50$.

WAR. (Groff). Extra fine large open flower well arranged on long, strong spike. Deep blood red. Each, 10c; \$1 per dozen.

White Excelsior. (Barre). Pure white except small crimson line in the throat. Flowers of good size. Plant very vigorous, growing extra tall. Each, 5c; 25c per dozen; per 100, \$1.50.

White Glory. (Kunderd). Pure ivory white with iris blue marking. Heavily ruffled. Each, 20c; \$2 per dozen.

WiLliam Copeland. Clear light bluish lavender with darker blotch. Extra good. Each, 10c; \$1 per dozen.

William Falconer. (Childs). Wide open, large pink flower. Long spike. Very popular. Each, 5c; 50c per dozen.

WILLIAM III. Bright glistening crimson slightly flushed white deep in throat. Especially good for bedding. Each, 10c; $\$ 1$ per dozen.

Willy Wigman. Very large, open, creamy white flower with conspicuous crimson blotches on lower petals. Each, $5 \mathrm{c} ; 25 \mathrm{c}$ per dozen; per 100, $\$ 2$.

Yellow Hammer. Pure yellow; extra strong grower. Award of Merit, 1913. Each, 10c; \$1 per dozen. 


\section{"The Modern Gladiolus Grower"}

I heartily recommend the "Modern Gladiolus Grower" to all those interested in the culture of the Gladiolus. It is a splendid and instructive monthly devoted solely to the Gladiolus, that old flower which has so recently been wonderfully improved. Read about the Gladiolus and keep abreast of the times in floriculture.

The "Modern Gladiolus Grower" aims to be helpful and indispensable to every grower, both professional and amateur. Practical notes and articles in each issue by those who know the business.

If you are not a reader of this paper or are a reader and wish it sent to a friend, I will, if requested, have it sent to any address, free, postpaid in the United States, upon receipt of retail orders from this catalog amounting to five dollars or over.

Published monthly by

MADISON COOPER,

Calcium, N. Y. 

